\title{
Efficient Production Process for Food Grade Acetic Acid by Acetobacter aceti in Shake Flask and in Bioreactor Cultures
}

\author{
HASSAN M. AWAD ${ }^{1,2}$, RICHARD DIAZ ${ }^{1}$, ROSLINDA A. MALEK ${ }^{1}$, NOR ZALINA \\ OTHMAN $^{1}$, RAMLAN A. AZIZ ${ }^{1}$, AND HESHAM A. EL ENSHASY ${ }^{1,3^{*}}$ \\ ${ }^{1}$ Institue of Bioproduct Development (IBD), Universiti Teknologi Malaysia (UTM), 81310, \\ Skudai, Johor, Malaysia \\ ${ }^{2}$ Chemistry of Natural and Microbial Products Department, National Research Centre \\ (NRC), Dokki, Cairo, Egypt \\ ${ }^{3}$ Bioprocess Development Department, City for Scientific Research and Technology \\ Applications, New Burg Al Arab, Alexandria, Egypt \\ hesham@utm.my
}

Received 10 October 2011; Accepted 03 December 2011

\begin{abstract}
Acetic acid is one of the important weak acids which had long history in chemical industries. This weak organic acid has been widely used as one of the key intermediate for many chemical, detergent, wood and food industries. The production of this acid is mainly carried out using submerged fermentation system and the standard strain Acetobacter aceti. In the present work, six different media were chosen from the literatures and tested for acetic acid production. The highest acetic acid production was produced in medium composed of glucose, yeast extract and peptone. The composition of this medium was optimized by changing the concentration of medium components. The optimized medium was composed of $(\mathrm{g} / \mathrm{L})$ : glucose, 100; yeast extract, 12 and peptone 5 and yielded $53 \mathrm{~g} / \mathrm{L}$ acetic acid in shake flask after $144 \mathrm{~h}$ fermentation. Further optimization in the production process was achieved by transferring the process to semi-industrial scale 16-L stirred tank bioreactor and cultivation under controlled $\mathrm{pH}$ condition. Under fully aerobic conditions, the production of acetic acid reached maximal concentration of about $76 \mathrm{~g} / \mathrm{L}$ and $51 \mathrm{~g} / \mathrm{L}$ for uncontrolled and controlled $\mathrm{pH}$ cultures, respectively.
\end{abstract}

Key words: Acetic acid, medium optimization, Acetobacter aceti, Food grade acetic acid, Semiindustrial process.

\section{Introduction}

Acetic acid $\left(\mathrm{CH}_{3} \mathrm{COOH}\right)$ is one of the simplest organic carboxylic acid. This colourless weak acid is characterized by distinctive sour taste and pungent smell. Nowadays, this acid is considered as one of the key intermediate for many industries including: chemical, 
detergent, wood and food industries. Currently, the production of acetic acid is carried out by chemical means using petrochemical feedstock or by the traditional approach of fermentative alcohol conversion using specific type of acetic acid bacteria. Among different chemical methods used, methanol carboxylation is the dominant production technology and accounting for over $65 \%$ of global capacity followed by ethylene oxidation, and alkane oxidation processes. Nowadays, acetic acid is an important as intermediate compound for the industrial production of different chemicals such as vinyl acetate polymer, cellulose acetate, terephthalic acid, dimethyl terephthalate, acetic acid esters/acetic anhydride and calcium magnesium acetate. All these products are made from petroleum-derived acetic $\operatorname{acid}^{1}$.

In spite of the fact that biological process for acetic acid production account for only $10 \%$ of global market production, it remain important process as many countries law stipulate that food grade vinegar must come from biological origin (fermentation). Therefore, optimization of biological process for acetic acid production is one of the most important industrial research and subject for study by many researcher groups using either free or immobilized cell systems ${ }^{2-7}$. For this bioprocess, there are several bacteria which can contribute to the production of acetic acid. Acetic acid bacteria were divided into five to six genera of which Acetobacter and Gluconabacter species can tolerate high concentration of acetic acid, which explain their use in vinegar production ${ }^{8}$. For industrial production, there are several species of Acetobacter that can be described as the main vinegar producer such as, $A$. aceti, A. pateurianus, $A$. peroxydans, A. orleaniensis, A. lovaniensis, A. estuniensis, $A$. malorum, A. cerevisiae and A. oeni. Therefore, Acetobacter is usually used in the production of vinegar from ethanol through acetaldehyde by consumed oxygen ${ }^{9}$. This production process is very sensitive for cultivation conditions applied and the chemical composition of the production medium. Carbon source used plays important role for bacterial growth and acetic acid production. It has been reported that, sugars such as: arabinose, xylose, ribose, glucose, galactose, mannose, melibiose, and trehalose can ferment by most of the Acetobacter strains ${ }^{10}$. However, the oxygen requirement for Acetobacter conversion makes the processes energy intensive. Other research also found that, the maximum production of acetic acid was achieved when cultivation medium was kept at $30{ }^{\circ} \mathrm{C}^{11}$. Nevertheless, the study was examined on dilution rates of bioreactor. However, the study which had been done by Zahoor and his group ${ }^{12}$ revealed that, Acetobacter aceti cells can grew in culture medium at temperature between $28{ }^{\circ} \mathrm{C}$ and $34^{\circ} \mathrm{C}$. Higher temperature up to $37{ }^{\circ} \mathrm{C}$ resulted in complete cell death.

Beside cultivation in batch mode, acetic acid production was also studies by using fed batch fermentation strategy. In repeated fed-batch fermentation, the product concentration from acetic acid achieved was about $80 \mathrm{~g} / \mathrm{L}$, but the number of viable cells at this product concentration was relatively low ${ }^{13}$. However, most of these studies were carried out using ethanol as main carbon and energy source. Compared to other carbon sources, ethanol is an expensive substrate and thus increase the production cost.

The current study is focused on optimization of acetic acid production process for high acetate production using glucose based cultivation medium. The first part of this research was focused on the effect of different medium components on the kinetics of cell growth and acetic acid production in small shake flask level. After medium optimization, cultivations were conducted in 16-L stirred tank bioreactor to evaluate the bioprocess scalability and production process under full controlled conditions in terms of agitation, aeration and $\mathrm{pH}$ control. 


\section{Materials and Methods}

\section{Microorganism}

The strain used throughout this work was Acetobacter aceti NRRL B-999. This strain was kindly provided in lyophilized form from ARS culture collection (Peoria, IL, USA). The lyophilized cells were activated first in Yeast Peptone mannitol medium (YPM) and cultivated in incubator shaker for $24 \mathrm{~h}$ at $28^{\circ} \mathrm{C}$. The obtained cells were subcultured on YPM medium supplemented with agar $20 \mathrm{~g} / \mathrm{L}$. The grown colonies were harvested in $50 \%$ glycerol and subsequently stored in cryovials for cell banking at $-80{ }^{\circ} \mathrm{C}$ to minimize the productivity loss by subsequent cultivations of cells. Each experiment was started by revival of one glycerol vial in vegetative culture.

\section{Inoculum preparation}

Inoculum was prepared in a $250 \mathrm{ml}$ Erlenmeyer flask containing $50 \mathrm{ml}$ YPM medium composed of $(\mathrm{g} / \mathrm{L})$ : yeast extract, 5, peptone, 3 and mannitol, 25. After sterilization for 15 min at $121^{\circ} \mathrm{C}, 50 \mathrm{ml}$ YPM medium was inoculated with $250 \mu \mathrm{l}$ of glycerol culture. The inoculated flasks were incubated on the rotary shaker (Innova 4080, New Brunswick Scientific Co., NJ, USA) at $200 \mathrm{rpm}$ and $28^{\circ} \mathrm{C}$ for $24 \mathrm{~h}$. Cells were used thereafter to inoculate either $250 \mathrm{ml}$ Erlenmeyer flasks or stirred tank bioreactor with inoculum concentration of $10 \%(\mathrm{v} / \mathrm{v})$.

\section{Screening media for acetic acid production}

Six different media were used in this study for primary evaluation for primary selection of the highly productive medium. All these media were reported before for their ability to support cell growth and acetic acid production by $A$. aceti. The composition of these media were as follows in (g/L): Medium (1): Glucose, 10; $\mathrm{K}_{2} \mathrm{HPO}_{4}, 0.1 ; \mathrm{KH}_{2} \mathrm{PO}_{4}, 0.9 ;\left(\mathrm{NH}_{4}\right)_{2} \mathrm{SO}_{4}$, $1.5 ; \mathrm{MgSO}_{4} .7 \mathrm{H}_{2} \mathrm{O}, 0.2 ; \mathrm{NaCl}, 0.01 ; \mathrm{FeSO}_{4} .7 \mathrm{H}_{2} \mathrm{O}, 0.01 ; \mathrm{MnSO}_{4} . \mathrm{H}_{2} \mathrm{O}, 0.01 ;$ Yeast extract, 10 ; $0.1 \mathrm{M}$ Citric acid, $50 \mathrm{ml}, \mathrm{pH} 5.0^{14}$; Medium (2): Yeast extract, 5; Peptone, 2; Glycerol, 30, pH $6.3^{15}$; Medium (3): Yeast extract, 5; Peptone, 2; Glucose, 30. pH 6.3 ${ }^{15}$; Medium (4): Ethanol, 47.4; Glucose, 1; Peptone, 2; Yeast extract, 5; Acetic acid, 10. pH 6.3 ${ }^{16}$; Medium (5): Glucose, 2; Yeast extract, 3; Polypeptone, 2.; Glycerol, 3, pH 6.5 9. Medium (6): Glucose, 100; Yeast extract, 3; Polypeptone, 2; Glycerol, 3 at $\mathrm{pH} 6.5^{9}$. The carbon source of each medium was sterilized separately and added to the fermentation medium before inoculation. The inoculated flasks were incubated on the rotary shaker (Innova 4080, New Brunswick Scientific Co., NJ, USA) at $200 \mathrm{rpm}$ and $28^{\circ} \mathrm{C}$.

\section{Medium Optimization}

For acetic acid medium optimization experiments, the strain was cultivated on medium No. 3 which composed of $(\mathrm{g} / \mathrm{L})$ : glucose, 30 ; polypeptone, 2; yeast extract, 5 with different glucose concentrations up to $120 \mathrm{~g} / \mathrm{L}$ and incubated on rotary shaker under the same conditions above mentioned. Subsequently, cultivations were conducted at different yeast extract concentrations $(0-15 \mathrm{~g} / \mathrm{L})$, followed by further investigation on the effect of peptone concentration $(0-6 \mathrm{~g} / \mathrm{L})$ on cell growth and acetic acid production.

\section{Bioreactor cultivations}

Cultivation in stirred tank bioreactor were conducted using the optimized medium in shake flask level and run under the same cultivation conditions in term of inoculums size, 
temperature and $\mathrm{pH}$. The bioreactor used in this study was $16-\mathrm{L}$ stirred tank bioreactor (BioEngineering, Wald, Switzerland) with working volume of 8-L. The stirrer was equipped with two 6-blade Rushton turbine impellers $\left(\mathrm{d}_{\mathrm{i} \text { (impeller diameter) }}=85 \mathrm{~mm} ; \mathrm{d}_{\mathrm{t} \text { (tank diameter) }}=214\right.$ $\mathrm{mm}, \mathrm{d}_{\mathrm{i}} / \mathrm{d}_{\mathrm{t}}=0.397$ ). The agitation speed was adjust to $600 \mathrm{rpm}$ and kept constant throughout the cultivation and aeration was performed using filtered sterile air and supplied continuously to the bioreactor with rate of $0.5 \mathrm{v} / \mathrm{v} / \mathrm{min}$. Foam was suppressed by the addition of silicon antifoam grade A (Sigma-Aldrich Inc., MO, USA). During the cultivation process, $\mathrm{pH}$ value and dissolved oxygen concentration were determined using $\mathrm{pH}$ and $\mathrm{DO}$ polarographic electrodes, respectively (Ingold, Mittler-Toledo, Switzerland). In case of $\mathrm{pH}$ controlled culture, the $\mathrm{pH}$ was adjusted to 6.3 by cascading the $\mathrm{pH}$ controller with acid/base feeding peristaltic pumps connected with $4 \mathrm{M} \mathrm{HCl}$ and $4 \mathrm{M} \mathrm{NaOH}$ solutions.

\section{Analysis}

Sample preparation and cell dry weight determination

Samples, in form of two flasks containing $50 \mathrm{ml}$ each, or $25 \mathrm{ml}$ of broth in case of bioreactor, were withdrawn at different times during the cultivation in a centrifugation falcon tube (Falcon, USA). Immediately after sampling, the optical density was measured by using spectrophotometer (DR/2500, Hach Co., Loveland, CO., USA) at $600 \mathrm{~nm}$ after proper dilution. For all samples, the cultivated broth was diluted to give values less than $\left(\mathrm{OD}_{600}\right)$ for better accuracy. The OD of culture was converted to dry cell mass through a linear correlation standard curve. Based on standard curve of this strain, One $\mathrm{OD}_{600}$ was almost equivalent to $0.3 \mathrm{~g} / \mathrm{L}$.

\section{Acetic acid determination}

Acetic acid was assayed according to the method of Pecina et al. ${ }^{17}$ which was modified later by Tomlins et al. ${ }^{18}$ using HPLC system (Waters, Milford, MA, USA). This system composed of a pump Waters 600 controller, 2690 Separation Module HPLC (Model 2690, Waters, Milford, MA, USA) and auto sampler fitted with a detection system; Ultraviolet (UV) 2487 Dual $\lambda$ Absorbance Detector at $210 \mathrm{~nm}$ (Water, Milford, MA USA). Separation was carried out using organic acid column: $300 \times 7.8 \mathrm{~mm} / 8$ micron (Phenomenex, Torrance, USA) was used to achieve the chromatographic separations. Acetic acid was eluted with $0.005 \mathrm{~N}$. sulphuric acid at a flow rate of $0.5 \mathrm{ml} / \mathrm{min}$ at $40{ }^{\circ} \mathrm{C}$. Peak heights were measured using a dual channel computer integrator (Water Empower chromatography system, Waters, Milford, MA, USA) and converted to acetic acid concentration based on previously prepared standard.

\section{Results and discussion}

\section{Screening media for acetic acid production}

Based on the previous published work, cell growth and acetic acid production were studied using six different cultivation media as described before in the materials and methods section. The inoculated flasks were incubated at $28^{\circ} \mathrm{C}$ on $200 \mathrm{rpm}$ for $96 \mathrm{~h}$. As shown in Figure 1, the maximal yield of acetic acid production of about $20.5 \mathrm{~g} / \mathrm{L}$ was recorded in medium No. 3 and medium No. 5 was the poorest for acetic acid production which produce only $11.5 \mathrm{~g} / \mathrm{L}$. Media No. 4, 2, 1 and 6 were the next best cultures for acetic acid production., respectively. 


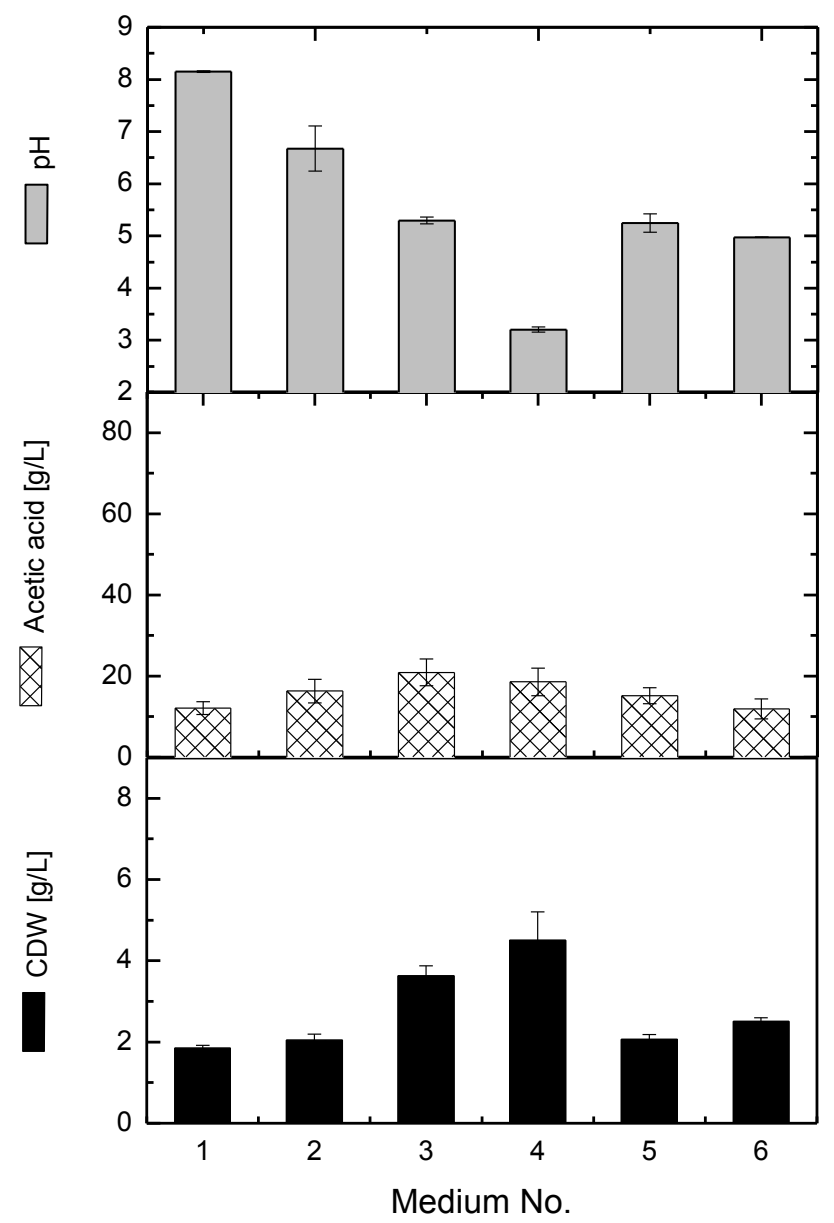

Figure 1. Cell growth and acetic acid production by Acetobacter aceti in different industrial media.

The best medium for acetic acid production was composed of $(\mathrm{g} / \mathrm{L})$ : glucose; 30, yeast extract; 5, and peptone; 2 . This obviously shows that, this medium has a high amount of carbon sources in form of glucose and thus supported high acetic acid production. The higher amount of carbon source, the high concentration of acetic acid can be produced. Acetic acid bacteria such as Acetobacter responded insensitive to the glucose and only somewhat sensitive in the presence of glycerol ${ }^{15}$. However, medium No. 4 has the high cell dry weight of $4.5 \mathrm{~g} / \mathrm{L}$ and the lowest $\mathrm{pH}$ of 3.21 compared to medium No. 3 . This medium contains high concentration of ethanol of $18.7 \mathrm{~g} / \mathrm{L}$ which make it not attractive in terms of manufacturing cost.

Medium No. 5 yielded the lowest concentration of acetic acid. This may be due to the lower amount of carbon source such as glucose and glycerol compared to the other media. A medium No. 1 gave acetic acid concentration of about $20 \mathrm{~g} / \mathrm{L}$.

\section{Optimal concentration of glucose for acetic acid production}

The aim of this experiment was to improve of acetic acid production through studying the effect of different glucose concentrations on the acetic acid production. Therefore, different glucose concentrations up to $120 \mathrm{~g} / \mathrm{L}$ were applied to investigate its effect on cell growth and 
acetic acid production. Figure 2 shows the data of cell growth and acetic acid production after $72 \mathrm{~h}$ cultivations. As shown, both of cell growth and acetic acid production were increased proportionally by increasing glucose concentration in the culture medium from 0 up to $100 \mathrm{~g} / \mathrm{L}$. The culture at initial glucose concentration $100 \mathrm{~g} / \mathrm{L}$ gave the maximum acetic acid production of about $30 \mathrm{~g} / \mathrm{L}$. Thus, the higher concentration of glucose, the higher concentration of acetic acid was produced. The $\mathrm{pH}$ value drastically decreased from 8.5 to 4.5 as the amount of glucose decreased.

On the other hand, the cell dry weight increased significantly from 0.8 to $7.0 \mathrm{~g} / \mathrm{L}$ as the amount of glucose increased from 0 to $120 \mathrm{~g} / \mathrm{L}$. Type and concentration of carbon source are important parameters on Acetobacter bacteria growth as well as the acetic acid production. In order to produce acetic acid in high concentration, ethanol or glucose can act as a main carbon source. It is important to get the pure products of acetic acid after fermentation by using a glucose which is from pure sugar. It was also reported that, different starchy carbohydrates and sugars such as: arabinose, xylose, ribose, glucose, galactose, mannose, melibiose, and trehalose can be utilized and support also acetic acid production by most of Acetobacter strains ${ }^{10,19}$.

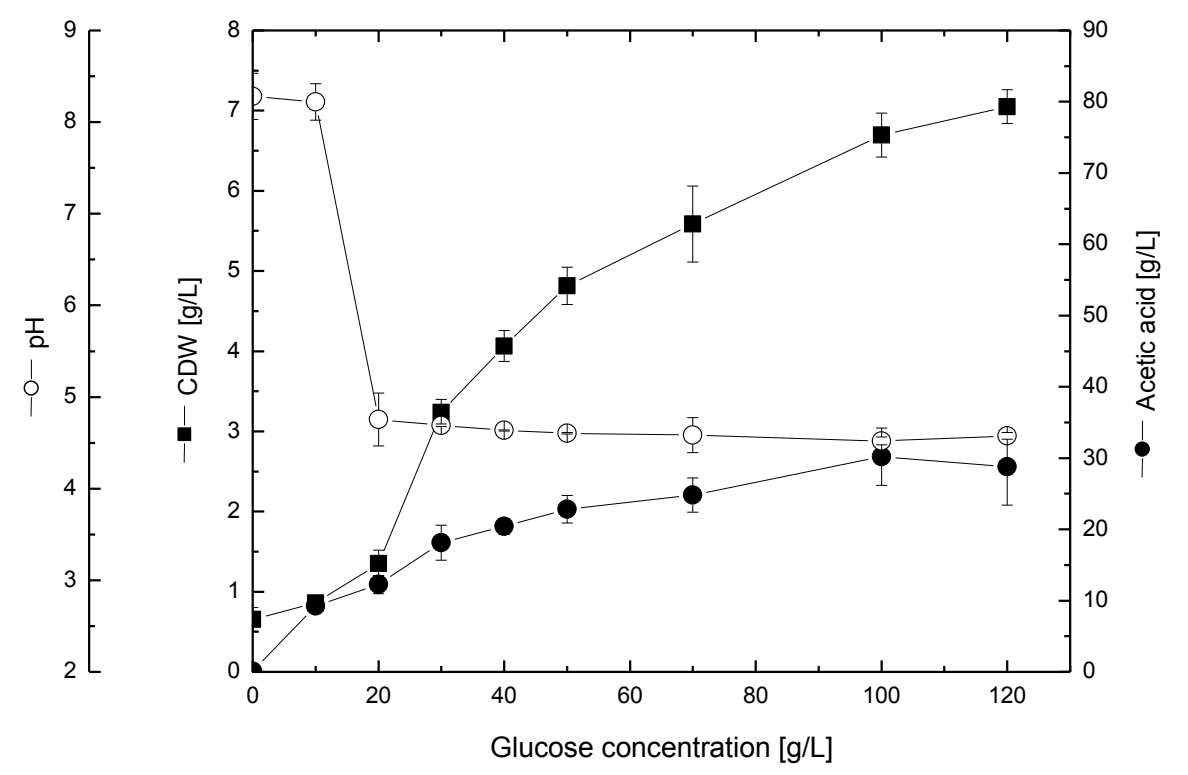

Figure 2. Effect of different glucose concentrations on cell growth, acetic acid production and $\mathrm{pH}$ during cultivation in shake flask culture.

\section{Effect of initial Yeast extraction concentrations on acetic acid production}

The influence of the yeast extract concentration, as one of the key nutrients, on the cell growth and acetic acid production was investigated. As shown in Figure. 3, the addition of yeast extract to the cultivation medium shows strong influence on both cell growth and acetic acid production. The cell growth increased with the increase of yeast extract concentration in the medium and reached its maximum of $7.4 \mathrm{~g} / \mathrm{L}$ at $15 \mathrm{~g} / \mathrm{L}$ yeast extract supplemented culture. On the other hand, the maximal acetic acid production of $41 \mathrm{~g} / \mathrm{L}$ was 
obtained in culture of $12 \mathrm{~g} / \mathrm{L}$ yeast extract. This amount of acetic acid produced was about 10 folds of that value obtained in a medium without yeast extract.

Based on its chemical composition, yeast extract is not only considered as the normal organic nitrogen source, but also it is an excellent source for many nutrients. It is rich with amino acids, vitamins and many low molecular weight growth factors. Therefore, yeast extract was widely used in the medium formulation for the production of cell mass and the induction of different primary and secondary metabolites ${ }^{20,21}$. On the other hand, $\mathrm{pH}$ value was decreased drastically from 6.0 to 4.5 as the amount of yeast extract increase from 0 to $15 / \mathrm{L}$. This gives also indirect indication for the increase in acetic acid production as function of the increased concentration of yeast extract.
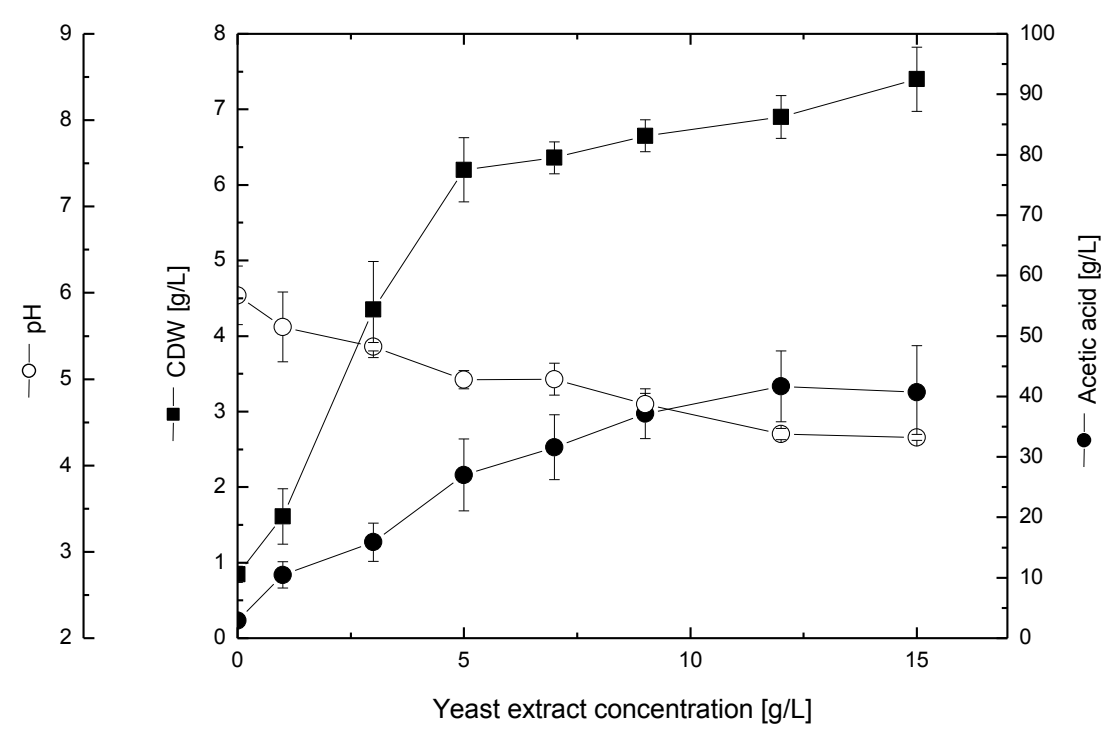

Figure 3. Effect of different yeast extract concentrations on cell growth, acetic acid production and $\mathrm{pH}$ during cultivation in shake flask culture.

\section{Effect of different of peptone concentration on acetic acid production}

The influence of peptone concentration on cell growth and acetic acid production is demonstrated in Figure. 4. As shown, like other medium components previously studied, peptone concentration shows a strong influence on both cell growth and acetic acid production. The cell growth increased with the increase of peptone concentration in the medium and reached its maximum of $8.7 \mathrm{~g} / \mathrm{L}$ in culture supplemented with $6 \mathrm{~g} / \mathrm{L}$ peptone. On the other hand, the maximal acetic acid production of $52.6 \mathrm{~g} / \mathrm{L}$ was obtained in of $5 \mathrm{~g} / \mathrm{L}$ peptone culture. This amount of acetic acid produced was more than 5 fold higher of those values obtained in the medium without peptone. Thus, we can conclude that peptone is equally important in culture like glucose and yeast extract. However, like other experiments, direct relation between the final $\mathrm{pH}$ value and acetic acid produced in culture. The $\mathrm{pH}$ was gradually decreased from $\mathrm{pH} 6.3$ to approximately $\mathrm{pH} 4.0$ when the peptone concentration increased in culture from 0 to $5 \mathrm{~g} / \mathrm{L}$. Further increase in peptone concentration didn't show any significant change in $\mathrm{pH}$ value. 

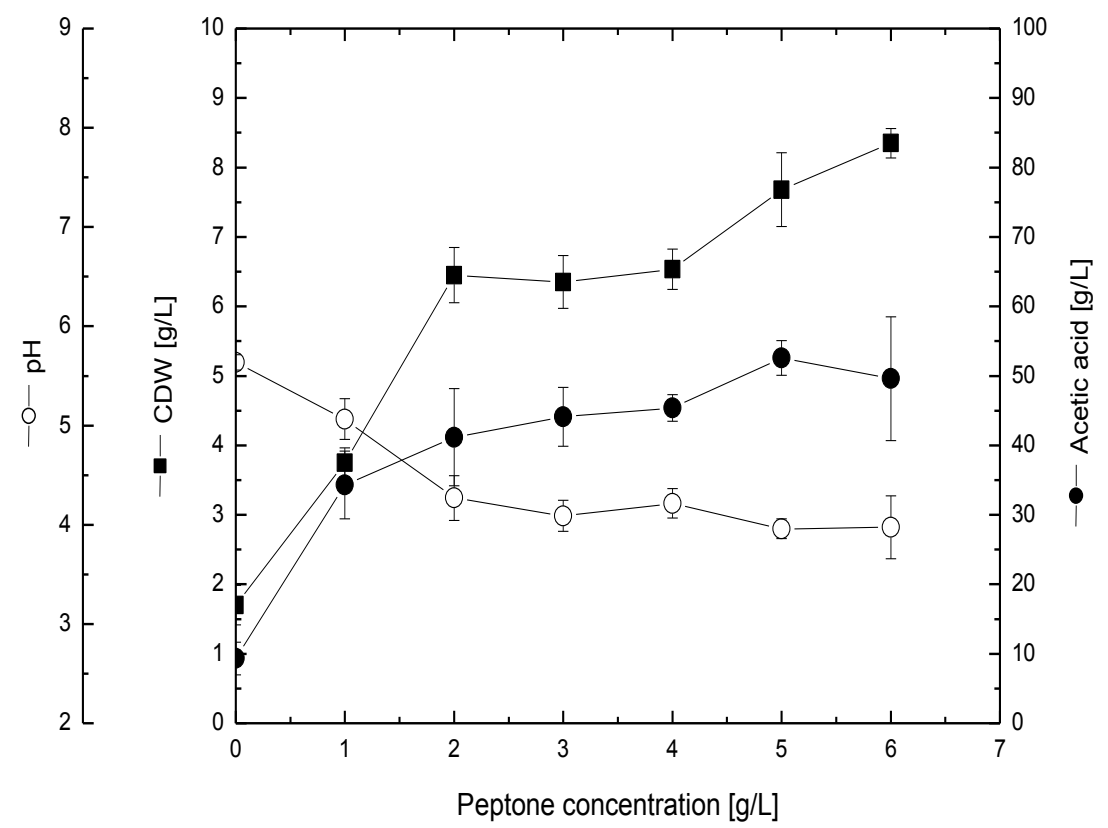

Figure 4. Effect of different peptone concentrations on cell growth, acetic acid production and $\mathrm{pH}$ during cultivation in shake flask culture.

Growth kinetics and acetic acid production by Acetobacter aceti in un-optimized and optimized medium.

Two parallel experiments were conducted to study the kinetics of cell growth and acetic acid production before and after optimization of medium composition in shake flask cultures. For both experiments, cultivations were conducted for $144 \mathrm{~h}$. During cultivation time, samples were taken at $24 \mathrm{~h}$ intervals and analyzed. As shown in Figure. 5, cells grew exponentially with different rates in both cultures. After $72 \mathrm{~h}$ cultivation, the cell growth in optimized medium was about $7.1 \mathrm{~g} / \mathrm{L}$. This value was about $115 \%$ higher than those obtained in medium before optimization. Further increase in cultivation time resulted in gradual increase in cell mass with very low rate reaching about $8.2 \mathrm{~g} / \mathrm{L}$ after $144 \mathrm{~h}$. On the other hand, for unoptimized culture, cell mass decrease gradually after reaching its maximal value of 3.3 $\mathrm{g} / \mathrm{L}$ after $72 \mathrm{~h}$ and dropped to about $2 \mathrm{~g} / \mathrm{L}$ after $144 \mathrm{~h}$. In parallel to cell growth in both cultures, the $\mathrm{pH}$ was dropped significantly and reached about 5 and 4.1, for medium before and after optimization, respectively. On the other hand, the maximal values of acetic acid production of $22 \mathrm{~g} / \mathrm{L}$ and $55 \mathrm{~g} / \mathrm{L}$ for medium before and after optimization, respectively, was obtained after $96 \mathrm{~h}$. Acetic acid concentration in both cultures kept more or less the same for further cultivation upto $144 \mathrm{~h}$. Thus, we can conclude that the new medium formula improved the acetic acid production process by more than 2 fold. 


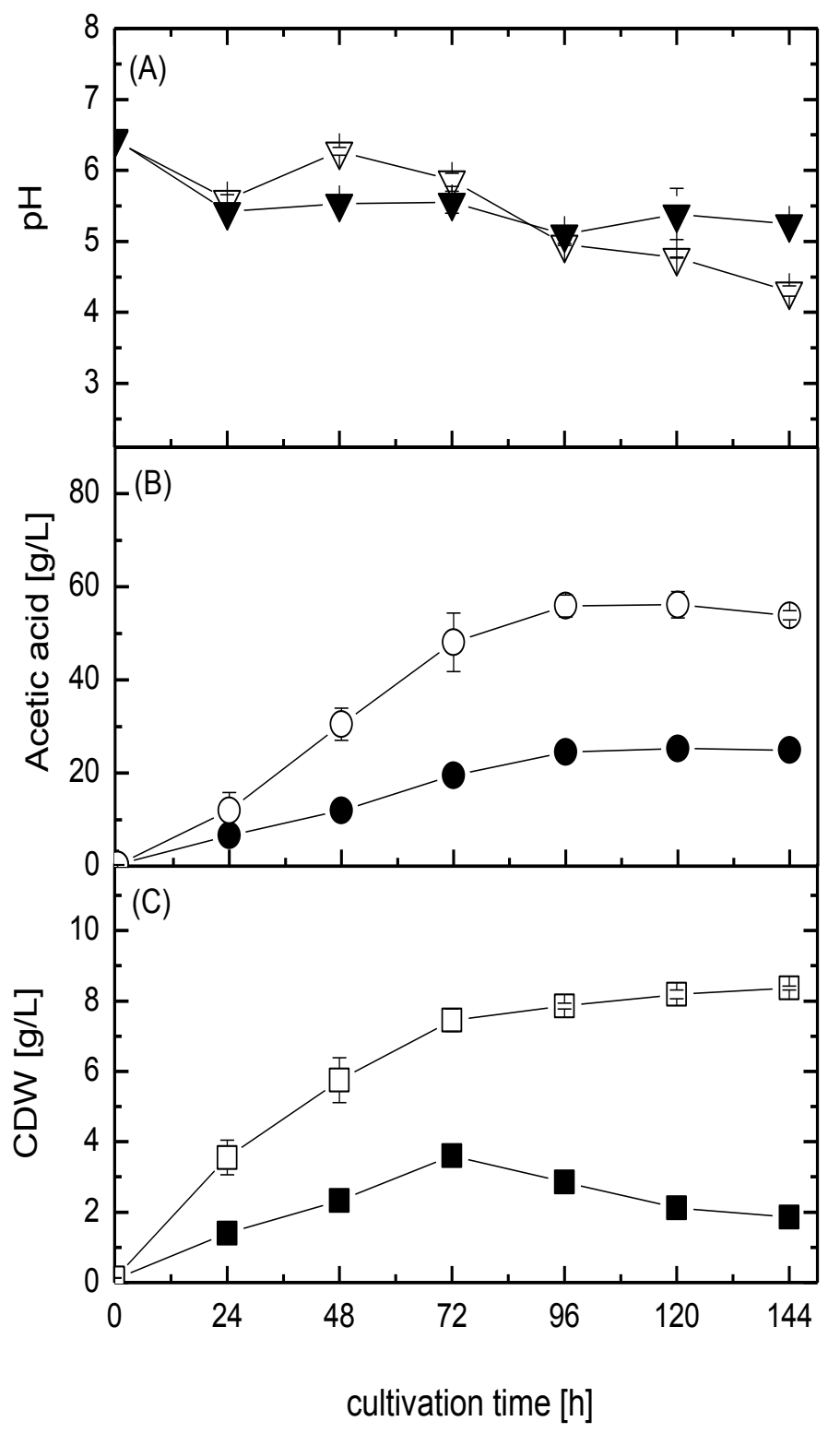

Figure. 5. Changes in Cell growth, acetic acid production and $\mathrm{pH}$ during cultivations in shake flask culture. Closed and opened symbols for medium before and after optimization, respectively.

Kinetics of cell growth and acetic acid production in semi-industrial scale 16-L stirred tank bioreactor using optimized medium in controlled and un-controlled $\mathrm{pH}$ cultures

Acetic acid production and cell growth were studied during batch cultivation of A. aceti in a pilot scale bioreactor using the same optimized medium composition and inoculum size used in shake flask experiments. Two parallel sets of experiments were performed using stirred 
tank bioreactor with 8-L working volume under controlled ( $\mathrm{pH}$ 6.3) and uncontrolled $\mathrm{pH}$ conditions. The results of batch cultivation under controlled culture condition are shown in figure 6 . Immediately after inoculation, cells grew exponentially with rate of $0.26 \mathrm{~g} / \mathrm{L} / \mathrm{h}$ and reached $6.2 \mathrm{~g} / \mathrm{L}$ after $24 \mathrm{~h}$. After that time, cells grew with lower rate reaching about $7 \mathrm{~g} / \mathrm{L}$ after $48 \mathrm{~h}$. In parallel, acetic acid was accumulated in culture with rate of $1.9 \mathrm{~g} / \mathrm{L} / \mathrm{h}$ and reaching its maximal value of $76 \mathrm{~g} / \mathrm{L}$ after $40 \mathrm{~h}$. During this phase glucose was utilized in culture with constant rate of $2.72 \mathrm{~g} / \mathrm{L} / \mathrm{h}$ and was fully consumed after $44 \mathrm{~h}$. However, during this the $\mathrm{pH}$ dropped gradually from 6.3 to 3.9 after $72 \mathrm{~h}$ as a result of active cell growth and acetic acid production in culture. It's also noteworthy to mention that, after acetic acid reached its maximal value after $40 \mathrm{~h}$, the acid concentration dropped gradually and reached $49.2 \mathrm{~g} / \mathrm{L}$ after $72 \mathrm{~h}$.

In parallel to this experiment, cultivation was conducted in $\mathrm{pH}$ controlled culture in stirred tank bioreactor. In this experiment, the $\mathrm{pH}$ value was kept constant at 6.3 by continuous addition of acid/based and controlled by computerized $\mathrm{pH}$ control system. As shown in figure 7, cells grew exponentially after cell inoculation with rate of $0.08 \mathrm{~g} / \mathrm{L} / \mathrm{h}$ and reached its maximal value of $3.52 \mathrm{~g} / \mathrm{L}$ after $44 \mathrm{~h}$. During this growth phase, acetic acid was also produced in culture with rate of about $1.17 \mathrm{~g} / \mathrm{L} / \mathrm{h}$ reaching $51.3 \mathrm{~g} / \mathrm{L}$ after $44 \mathrm{~h}$. During this growth and acid production phase, glucose consumed in culture with constant rate of 1.143 $\mathrm{g} / \mathrm{L} / \mathrm{h}$ and reached about $31 \mathrm{~g} / \mathrm{L}$ after $44 \mathrm{~h}$ (as cells inter stationary phase) and kept more or less constant for the rest of cultivation time. However, unlike $\mathrm{pH}$ uncontrolled culture, the acetic acid production was not decreased gradually in culture after reached its maximal value and kept more or less constant for the rest of cultivation time.

However, it was reported that, most of Acetobacter strains can grow effectively between $\mathrm{pH}$ 4.5 and 7.0, with very few exceptional strain who can grow at $\mathrm{pH} 8.0$ and $3.0^{10}$. Thus, the studied was within the range of the positive growth which was a good condition for the cell growth. This explains also the good growth of $\mathrm{pH}$ controlled and uncontrolled cultures. It have been also reported that the acetic acid fermentation for free and adsorb cells has an optimum range of $\mathrm{pH}$ between 5.2 and $6.2^{22}$.

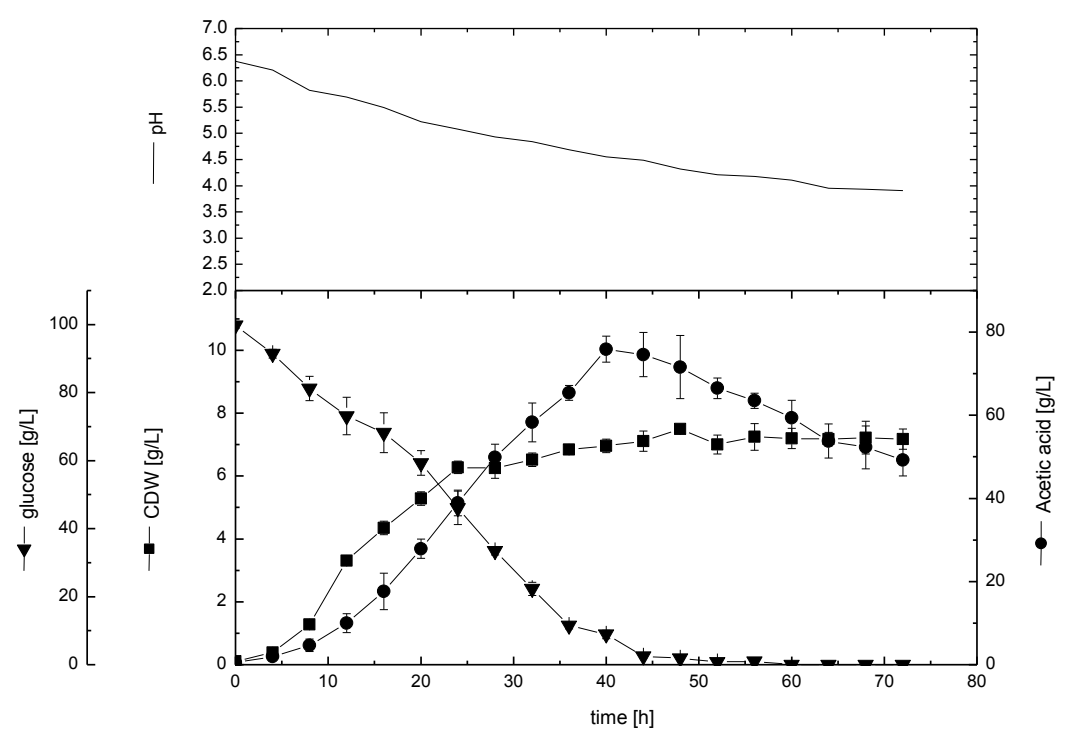

Figure 6. Batch cultivation for acetic acid production using bioreactor 16-L under uncontrolled $\mathrm{pH}$. 


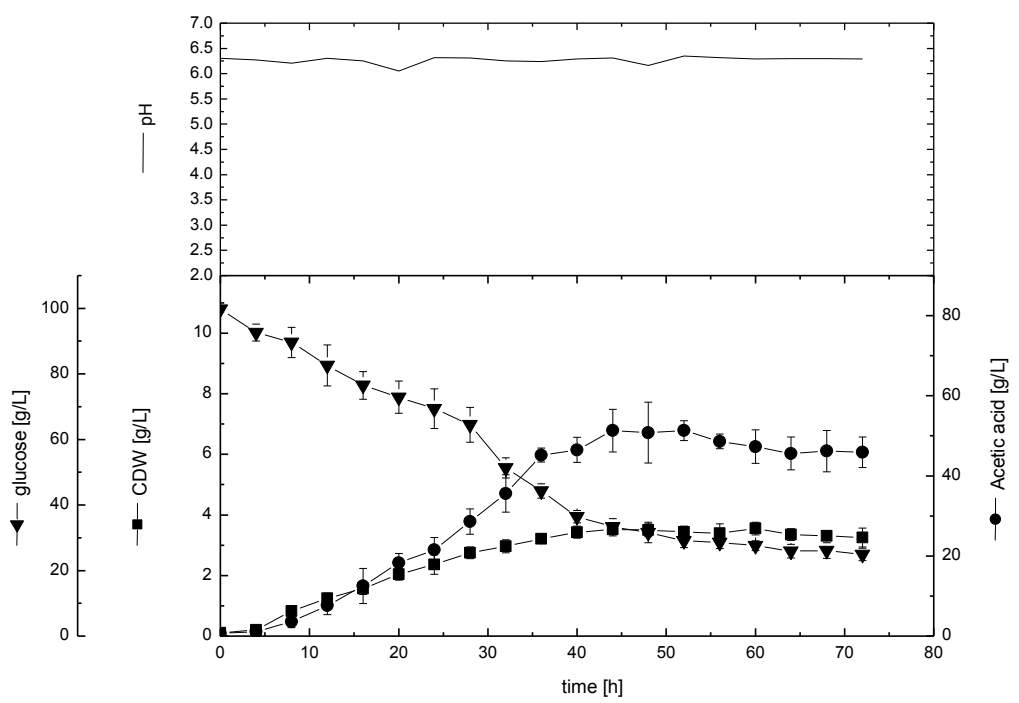

Figure 7. Batch cultivation for acetic acid production using bioreactor 16-L under controlled $\mathrm{pH}$.

\section{Conclusion}

Table 1 summarizes the kinetics of cell growth and acetic acid production when cells cultivation in shake flask and bioreactor under different cultivation conditions. As shown, optimization of growth medium resulted in significant increase in volumetric acetic acid production from only $22 \mathrm{~g} / \mathrm{L}$ upto $55 \mathrm{~g} / \mathrm{L}$ concomitant with 3 fold increases in acid production rate $\left[\mathrm{Q}_{\mathrm{p}}\right]$. Further improvement in the production process was achieved by process scaling up from shake flask to 16 -L stirred tank bioreactor. Maximal acid production of about $76 \mathrm{~g} / \mathrm{L}$ was achieved in non $\mathrm{pH}$ controlled culture after only $44 \mathrm{~h}$ cultivation. This process shows high potential for industrial scale production of acetic acid using glucose based and alcohol free medium.

Table 1. Kinetics of cell growth and acetic acid production in shake flasks and in bioreactor using different media and under cultivation conditions.

\begin{tabular}{|c|c|c|c|c|}
\hline \multirow[t]{2}{*}{ parameters } & \multicolumn{2}{|c|}{ Shake flask } & \multicolumn{2}{|c|}{ Bioreactor } \\
\hline & $\begin{array}{l}\text { Non-optimized } \\
\text { medium }\end{array}$ & $\begin{array}{c}\text { Optimized } \\
\text { medium }\end{array}$ & $\begin{array}{c}\mathrm{pH} \\
\text { uncontrolled }\end{array}$ & $\begin{array}{c}\mathrm{pH} \\
\text { controlled }\end{array}$ \\
\hline \multicolumn{5}{|c|}{$\begin{array}{r}\text { Growth parameters } \\
\end{array}$} \\
\hline$X_{\max }[g / L]$ & 3.30 & 8.20 & 6.20 & 3.52 \\
\hline dx/dt $[g / L / h]$ & 0.046 & 0.099 & 0.26 & 0.08 \\
\hline$\mu\left[\mathrm{h}^{-1}\right]$ & 0.020 & 0.028 & 0.084 & 0.045 \\
\hline \multicolumn{5}{|c|}{ Production parameters } \\
\hline$P_{\max }[g / L]$ & 22.0 & 55.0 & 76.0 & 51.3 \\
\hline$Q_{P}[g / L / h]$ & 0.23 & 0.76 & 1.90 & 1.17 \\
\hline$Q_{s}[g / L / h]$ & ND & ND & 2.72 & 1.43 \\
\hline$Y_{P / \mathbf{X}}[g / g]$ & 6.67 & 7.75 & 10.94 & 14.91 \\
\hline
\end{tabular}

$\mathrm{X}_{\max }$ : maximal cell dry weight, $\mathrm{dx} / \mathrm{dt}$ : growth rate, $\mu$ : Specific growth rate, $\mathrm{P}_{\max }$ : maximal acetic acid production; $\mathrm{Q}_{\mathrm{P}}$ : acetic acid production rate; $\mathrm{Q}_{\mathrm{s}}$ : glucose consumption rate, $Y_{\mathrm{P} / \mathrm{X}}$ : specific acetic acid production ( $\mathrm{g}$ acetic acid produced per $\mathrm{g}$ cell dry weight). 


\section{References}

1. Kim JS, Kim H, Oh K K and Kim YS. J. Ind. Eng. Chem., 2002, 8, 519-523.

2. Lu S.-F; Lee FL and Chen H-K J. Appl. Microbiol., 1999, 86, 55-62.

3. Berraud C. Biotechnol. Lett., 2000, 22, 451-454.

4. Ory I, Romero LE and Cantero D. Process Biochem., 2004, 39, 547-555.

5. Nishiwaki A and Dunn IJ. J. Chem. Technol. Biotechnol, 2005, 80, 371-375.

6. Kocher, G. S., Kalra, K. L. and Phutela, R. P. J. Inst. of Brew., 2006, 112, 262-266.

7. Jiménez-Hornero J, Santos-Duenas IM and Garcia-Gaarcia I. Biochem. Eng. J., 2009, 45, 7-21.

8. Yamada Y, Katsura K, Kawasaki H, Widyastuti Y, Saono S, Seki T, Uchimura T and Komagata K. Int. J. Evol. Microbiol., 2000, 50, 823-829.

9. Kondo T and Kondo M. J. of Ferment. Bioeng., 1996, 81, 42-46.

10. Kadere TT, Miyamoto T, Oniang ORK, Kutima PM and Njoroge SM. Afr. J. Biotechnol., 2008, 7, 2963-2971.

11. Park YS and Toda K. Biotechnol. Lett., 1992, 14, 609-612.

12. Zahoor T, Siddique F and Farooq U. British Food J., 2006, 108, 429-43.

13. Ito T, Sota H, Honda H, Shimizu K and Kobayashi T. Appl. Microbiol. Biotechnol., 1991, 36, 295-299.

14. Ationu A, Patterson JDE, Todd JR Wood BJB. Biotechnol. Lett., 1988, 10, 671-676.

15. Lasko DR, Zamboni N and Sauer U. Appl. Microbiol. Biotechnol., 2000,.54, 243-247.

16. Toda K, Park YS, Asakura T, Cheng CY and Ohtake H. Appl. Microbiol. Biotechnol., 1989, 30, 559-563.

17. Pecina R, Born G, Burtscher E and Bobleter O. J. Chromatograph., 1984, 287, 145258.

18. Tomlins KI, Baker DM, McDowell IJ. Chromatographia., 1990, 29, 557-561.

19. Tan SC. (2005). Degree of Master of Science, Agricultural and Mechanical College, University of Louisiana at Lafayette. Lafayette Parish, Louisiana, United States. http://etd.lsu.edu/docs/availableletd-11092005-152334/unrestricted/Tan thesis.pdf

20. Amrane A and Prigent Y. World J. Microbial. Biotechnol., 1998, 14, 529-534.

21. El-Enshasy, H.; Hellmuth, K and Rinas, U. Appl. Biochem. Biotechnol., 1999, 81, 1-11.

22. Krisch J and Szajáni B. Biotechnol. Lett., 1996, 18, 393-396. 


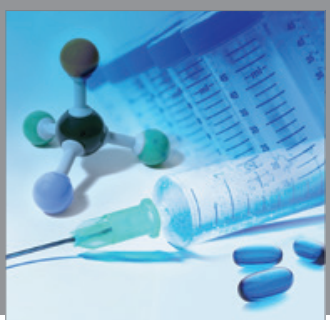

International Journal of

Medicinal Chemistry

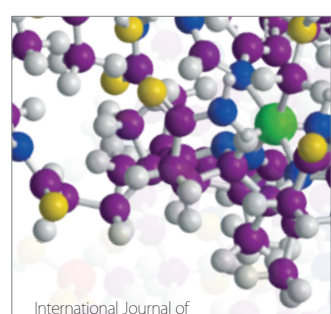

Carbohydrate Chemistry

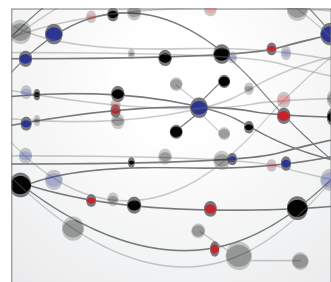

The Scientific World Journal
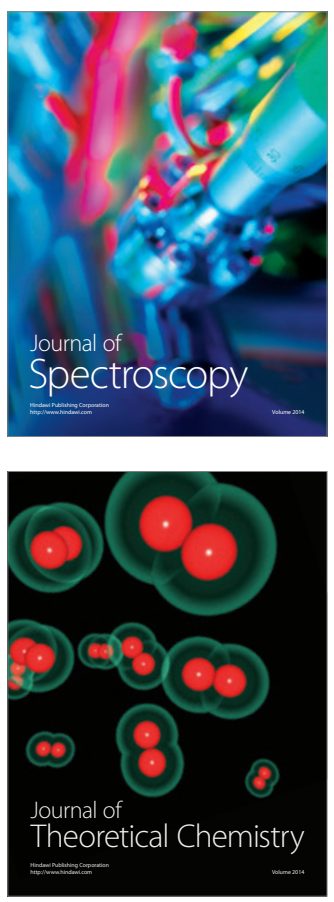
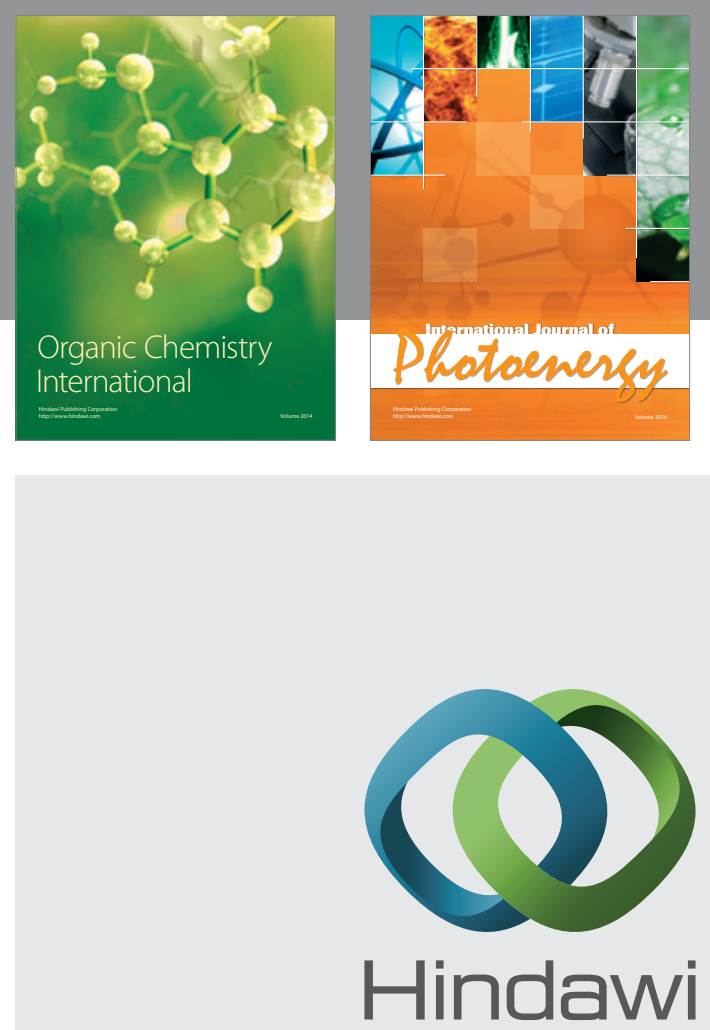

Submit your manuscripts at

http://www.hindawi.com
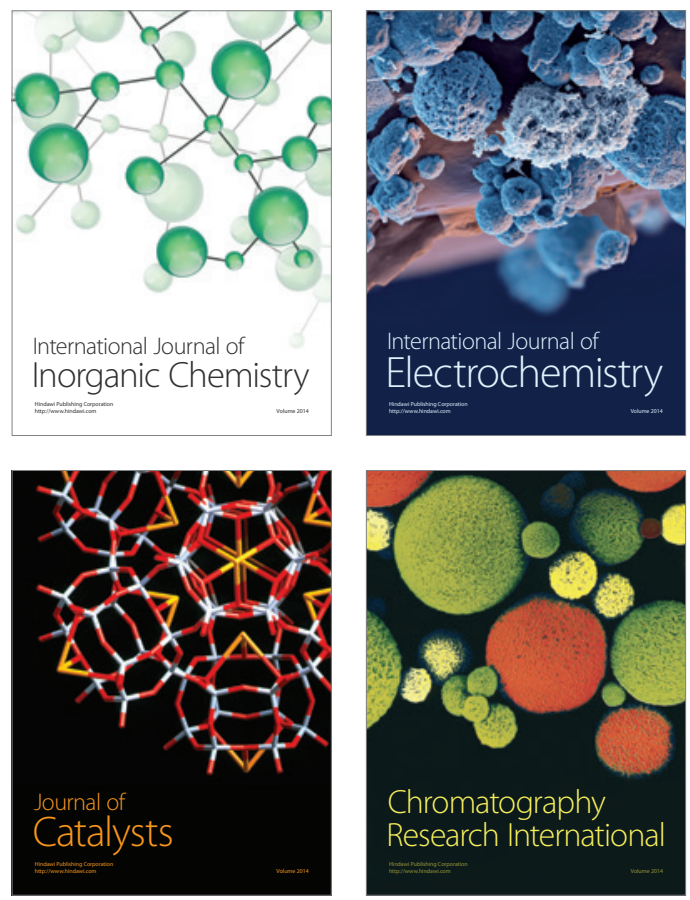
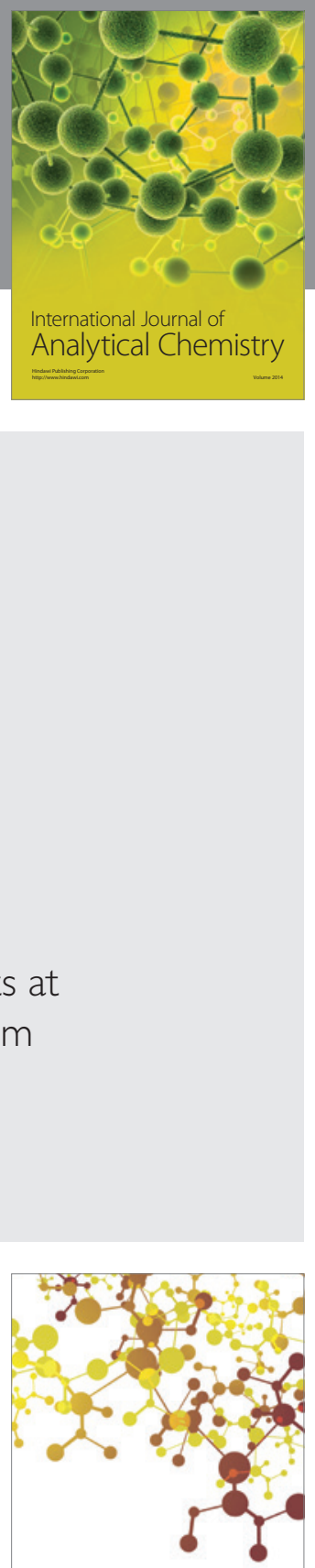

Journal of

Applied Chemistry
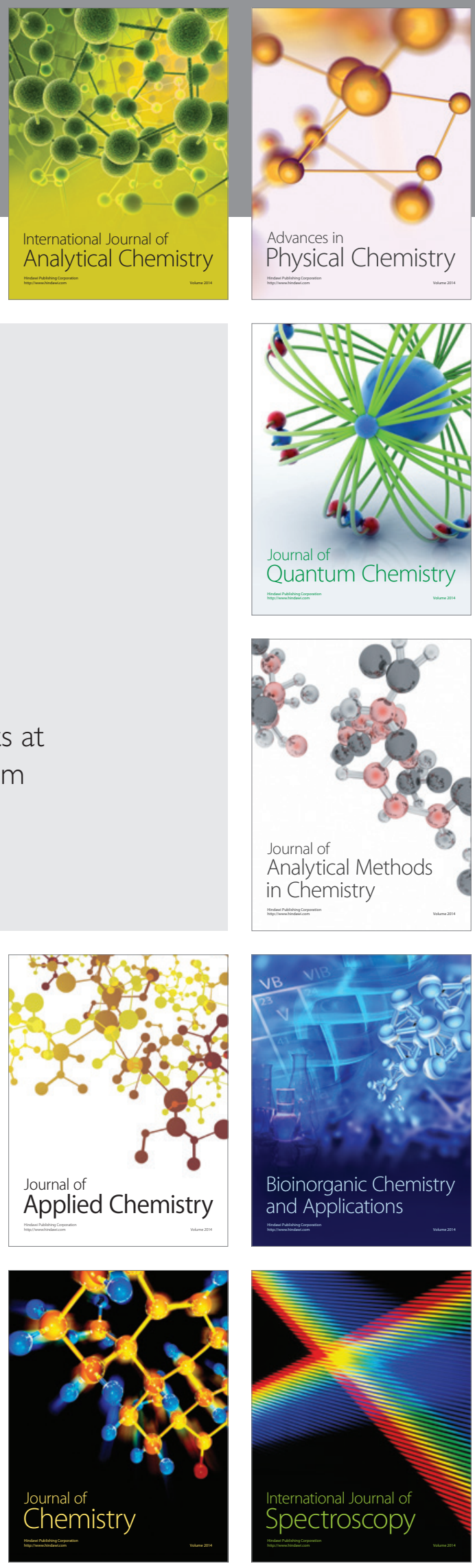